\title{
Industrial Engine Integrated Program Plan Task 7
}

\author{
Topical Report \\ May 1997
}

RECEIVED

FFR 131998

OSTI

Work Performed Under Contract No.: DE-AC21-93MC30244

For

U.S. Department of Energy

Office of Fossil Energy

Federal Energy Technology Center

Morgantown Site

P.O. Box 880

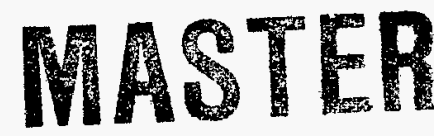

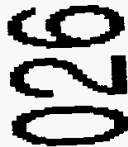

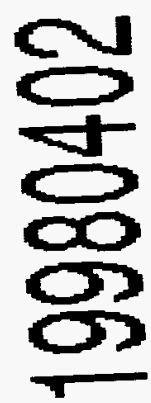

Morgantown, West Virginia 26507-0880

By

GE Power Systems

1 River Road

Schenectady, New York 12345

IITC QUALTYY IMREEUTED a 


\section{Disclaimer}

This report was prepared as an account of work sponsored by an agency of the United States Government. Neither the United States Government nor any agency thereof; nor any of their employees, makes any warranty, express or implied, or assumes any legal liability or responsibility for the accuracy, completeness, or usefulness of any information, apparatus, product, or process disclosed, or represents that its use would not infringe privately owned rights. Reference herein to any specific commercial product, process, or service by trade name, trademark, manufacturer, or otherwise does not necessarily constitute or imply its endorsement, recommendation, or favoring by the United States Government or any agency thereof. The views and opinions of authors expressed herein do not necessarily state or reflect those of the United States Government or any agency thereof. 


\section{TASK 7-INTEGRATED PROGRAM PLAN}

\subsection{TASK OBJECTIVE}

Define and develop an engine program that will develop and demonstrate the overall objectives of the Advance Turbine Program as outlined for Task 3.

\subsection{INTEGRATED PROGRAM PLAN}

For the engine configuration of Task 6, General Electric has identified a program which would lead to the demonstration of an ATS Industrial system which could possibly achieve the program goals for efficiency, emissions and costs. The integrated program plan consists of a nine task effort outlined as follows:

\section{Task 1-Preliminary Design}

This task will complete the preliminary design of the engine system from the concept developed in Task 6 of the Advanced Turbine System Program.

\section{Task 2- Detail Design}

This task will result in an engine final configuration and detail drawings being provided for hardware procurement.

\section{Task 3- Hardware Procurement}

This task will procure all engine and associated test hardware to conduct full scale engine testing of the ATS Industrial engine.

\section{Task 4- Engine Assembly}

This task's purpose is the assembly of a core engine for test and post test core engine assembling with its matching power turbine.

\section{Task 5- Core Engine Test}

This task is used to determine the operating characteristics of the high pressure engine system which is made up of the high pressure compressor, combustor, turbocooler, and high press turbine.

\section{Task 6- Full Engine/No Load Test}

This task is used to determine the operating characteristics of the core engine mated to the booster, intercooler and low pressure turbine system.

Task 7-Installation and Site Test

This task is used to install the full engine system for testing under load at a participating utility or power generation company.

\section{Task 8-Prototype Testing}


This task is used for the full engine testing of the engine system under load at the participating utility or power generation company.

\section{Task 9-Data Evaluation}

This task is used to review engine test data and to determine if the program goals have been met by the demonstration test of Task 8 .

Figure 7.1.1 shows the program plan with the major tasks and the timing of those tasks. To demonstrate the program goals, the resulting program is estimated to be a five-year program. 


\section{ADVANCE INTERCOOLED CYCLE PROJECT}

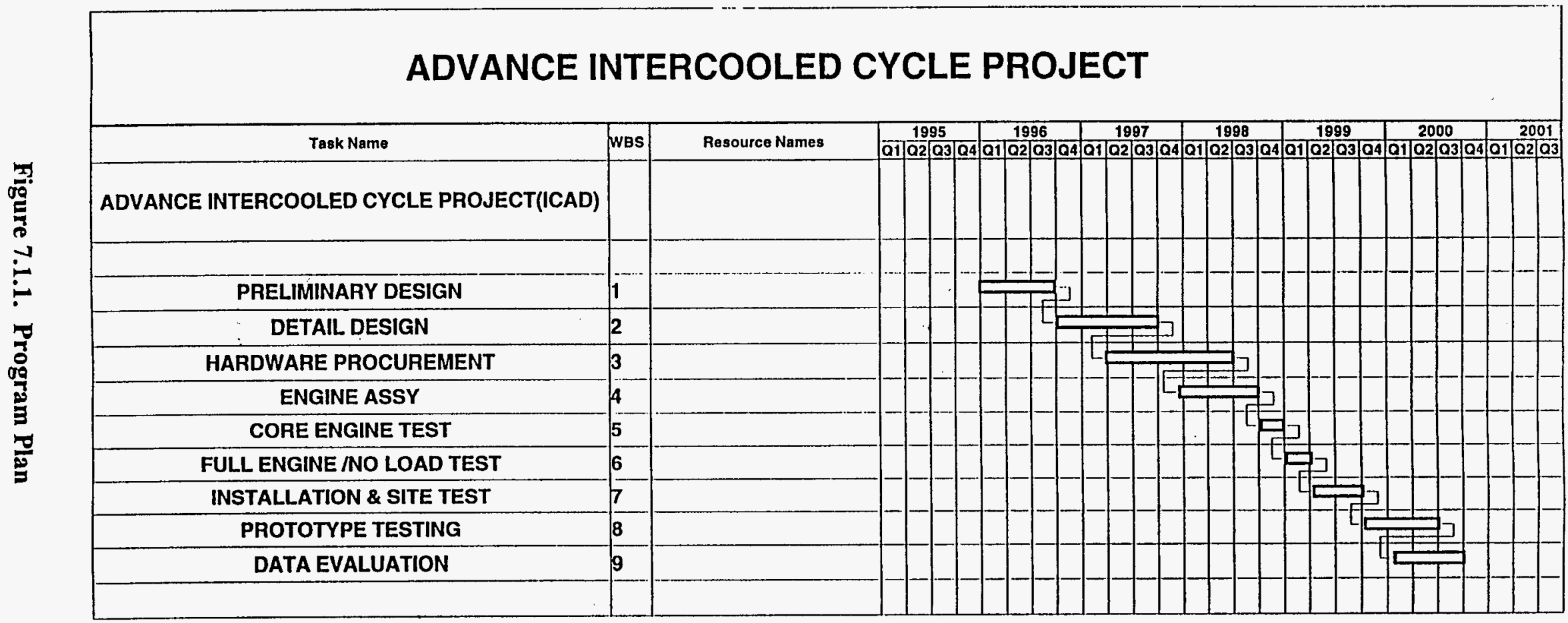




\subsection{RISK ASSESSMENT}

Risks and challenge areas have been identified in Task 6 and are in the following general areas:

- Cycle pressure levels

- Turbocooler development

- Fuel heating and fire safety

- Combustor emissions development

- Combustor cooling

- High pressure vane cooling

- Thermal barrier coating development for the combustor and high pressure turbine vane

- Low-pressure turbine cooling

These risk areas will be addressed in Task 2 during the detail design phase. 
M98002023

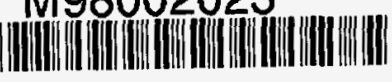

Report Number (14) DOE $/ \mathrm{mc} / 30244--58 / 6$

subl. Date (11) 499705

sponsor code (18) DOE/FE, XF

JC Category (19) UC-101, DOETER

DOE 